\title{
Study on a Fully Electrified Car Ferry Design Powered by Removable Battery Systems Considering Domestic Coastal Environment
}

\author{
Jang Pyo Hong ${ }^{\circledR 1}$, Young-Shik Kim ${ }^{\circledR 1}$, Hyung-Won Shim ${ }^{\circledR 1}$, Hee-Jin Kang ${ }^{\circledR 1}$, \\ YunHo Kim ${ }^{1}$, Gyu Bum Kim ${ }^{\circledR 1}$ and Seongpil Cho ${ }^{1}$ \\ ${ }^{1}$ Alternative Fuels and Power System Research Center, Korea Research Institute of Ships and Ocean Engineering, Daejeon, Korea
}

KEY WORDS: Battery-powered car ferry, Removable power supply system, Roll-on/roll-off battery system, Fully electrified car rerry, Eco-friendly ship design

\begin{abstract}
As increasing the international community's awareness of greenhouse gas reduction, the demand for eco-friendly ship fuel has accelerated recently. The fundamental aim of this study is to develop a new type of fully electrified ferry for passengers and cars considering Korean domestic coastal environmental conditions. Several technical difficulties are encountered in applying a fully electric propulsion system based on removable battery systems into a ship due to limitations imposed by the batteries' size and capacity. This paper reviews and analyzes marine environment regulations strengthened recently, technology trends related to fully electric propulsion vessels in each country, and Korean domestic coastal environments. We propose a new fully electrified car ferry design with a displacement of $400 t$ applied in Korea. It is powered by removable battery systems pre-charged in a safe inland charging station. The mobile battery system is developed to enable roll-on and roll-off using wheels. The characteristics of the ship motion are analyzed based on the weight and location of the battery systems. We expect our battery systems to be applicable to larger ships in the future.
\end{abstract}

\section{Introduction}

The temperature on Earth has been increased by $0.74{ }^{\circ} \mathrm{C}$ due to human activities over the past century. When the body temperature rises by 1 or $2{ }^{\circ} \mathrm{C}$, a human feels the strangeness of health. Likewise, Earth temperature changes have resulted in various environmental abnormal phenomena, such as sea ice melting and desertification. Furthermore, temperature changes caused by global warming are causing extreme weather events, such as heat waves, large hurricanes, droughts, typhoons, heavy rains, and heavy snow in areas inhabited by humans. The main cause of global warming is carbon dioxide. Carbon dioxide is primarily emitted from fossil fuels used by humans. It is accumulated in the atmosphere and causes the greenhouse effect, thereby negatively affecting living organisms and humans' survival. The international community has recognized this problem, and members of the United Nations (UN) have agreed to the obligation of greenhouse gas (GHG) reduction at the 21st General Assembly of the Parties to the UN Framework Convention on Climate Change held in Paris in 2015. This UN obligation of GHG has been applied to all 195 UN member countries from January 2021. The convention presents the long-term goal of maintaining the global average temperature increase below $2{ }^{\circ} \mathrm{C}$.

Among anthropogenic GHG emissions, the shipping sector's contribution increased from 800 million tons in 2012 to 1 billion tons in 2018 , constituting approximately $3 \%$ of the total global emissions. Hence, GHGs generated from the shipping industry must be reduced urgently. In April 2018, the International Maritime Organization (IMO) announced an early strategy to reduce GHGs emitted from ships by $50 \%$ compared with those emitted in 2008 and has continuously expressed the importance of reducing GHG emissions (Kim et al., 2018). To reduce GHGs in the shipping industry, the existing ships must be transformed into eco-friendly systems. To comply with environmental regulations, the global shipping industry changes ship fuels from heavy fuel oil (HFO) to liquefied natural gas (LNG) or marine diesel oil. And the additional emission reduction systems such as scrubber systems for SOx reduction and selective catalytic reduction systems for NOx reduction are installed on the ships (Lee, 2018). However, the solutions for GHG reduction in the shipping sector are still insufficient to achieve the IMO's GHG reduction goal. One of the well-known practical alternative solutions

Received 16 October 2020, revised 30 December 2020, accepted 30 December 2020

Corresponding author Young-Shik Kim: +82-42-866-3951, yskim@kriso.re.kr

(C) 2021, The Korean Society of Ocean Engineers

This is an open access article distributed under the terms of the creative commons attribution non-commercial license (http://creativecommons.org/licenses/by-nc/4.0) which permits unrestricted non-commercial use, distribution, and reproduction in any medium, provided the original work is properly cited. 
for implementing the GHG reduction strategy during ships' operation is operating them at low speed, i.e., less than $50 \%$ of the specified ship speed, resulting in undesirable repercussions to the shipping industry. Hence, various alternative fuels applicable to ships must be developed. The stable fuel-supplying to automobiles and industrial machines in one country is not a big issue. However, owing to the nature of the shipping industry, which requires fuels worldwide, the fuel-supplying stability is critical for the development of alternative fuels for the shipping industry.

Electric energy with battery systems is strongly attracting attention as an alternative eco-friendly fuel for shipping. Electric energy guarantees fuel-supplying stability because it is produced in every country. And zero-emission is realized in the operation of the ships with electrical propulsion systems. However, it is difficult to apply the battery system to large ocean-crossing vessels due to the energy density problems concerning volume, weight, and cost. Hence, it would be desirable to promote battery usage as ship fuel by securing related technology development through their application to relatively small vessels operating near the seashore. Recently, performance evaluation techniques for electric propulsion systems have been investigated as an element technology for eco-friendly ships to reduce air pollutant emissions (Joung et al., 2013). Furthermore, a prototype of a $20 \mathrm{HP}$-class outboard electric motor drive system was developed, and its performance was evaluated (Moon et al., 2018). However, electric propulsion vessels using the battery system as the main power source have not been investigated.

In this study, recent technology issues relating to the fully electric propulsion system are investigated by analyzing technology development and research projects in major countries for realizing IMO's GHG reduction strategies. And also, the developing status of fully electrified vessels over the world is analyzed. In addition, vessel types applicable to the current technology level of fully electric propulsion vessels that do not emit GHGs during the operation are analyzed. Based on the analysis results, a conceptual design of a fully electrified ferry for passengers and cars powered by removable power supply systems that is suitable for coastal environments with significant tidal differences and frequent typhoons such as Korea.

\section{IMO's Initial Strategy for Reducing GHG Emissions and Characteristics of Alternative Fuels}

\subsection{IMO's Initial Strategy for Reducing GHG Emissions}

South Korea's GHG emission in the shipping sector was approximately 800 million tons in 2012, greater than those of Germany, which ranked the sixth in the world. Therefore, efforts to reduce GHG emissions in the shipping sector are essential (Kim et al., 2018). The Marine Environment Protection Committee of the IMO adopted an initial strategy to implement GHG reduction in the shipping sector in the committee's 72nd session. The strategy's vision was to commit to reducing GHG emissions from international shipping and phase them the soonest possible.

To achieve the initial strategy goal, the IMO derived short-term, mid-term, and long-term measures to reduce GHG emissions in ships, as shown in Table 1. After reviewing (1) the geographic access and connectivity to key markets, (2) value and type of cargo, (3) dependence on transport, (4) transport costs, (5) food security, (6)

Table 1 IMO's strategic measures for reducing greenhouse gas emissions in ships

Period Content

- Additional improvements of energy efficiency systems focused on EEDI and SEEMP

- Development of technical and operational measures based on a three-step approach with indexes for performance measurement and improvement of ship energy efficiency for new and existing ships

- Program establishment for improvement of an existing ship

- Review of speed optimization considering operational safety, market distortion, and maritime transport capacity

- Strengthen measures for treatment of methane and volatile organic compounds (VOCs)

- Development of policies and strategies for reduction of greenhouse gas emissions from international transport in according to IMO guidelines

Short-term - Continuous technical cooperation with ITPC activities

- Port developments for the power supply to onshore/offshore regions and ships through renewable energy, infrastructure for low or zero carbon emission fuel supplies, and the optimization of logistics networks and plans

- Establishment of the International Maritime Research and Development Board (IMRB) to improve ship propulsion, alternative low or zero carbon emission fuel, and ship energy efficiency and to supervise R\&D support

- Incentive payments for developing and adopting new technologies

- Guideline development of greenhouse gas/carbon intensity for all fuel types

- Promotion of emission reduction efforts according to IMO-level to the international community

- Investigation of additional GHG Study and policy establishment regarding regulations for zero carbon emission fuel

- Program development for ensuring alternative low carbon and zero emission fuel

- Operational energy efficiency measures based on a three-step approach with indexes for new and existing ships

Mid-term - Emission reduction measures considering market-based measures (MBMs)

- Continuous promotion of technical cooperation (e.g. ITCP) and capacity enhancement activities

- Development of feedback measures for information exchange on best cases 
disaster response, (7) cost-effectiveness, and (8) socio-economic progress and development, the IMO urged every member country to analyze the effects and seek solutions if adverse effects to short-term approaches are identified.

If the ship fuel consumption can be reduced, then GHG emissions can be reduced. Shipping is a logistics industry that constitutes more than $90 \%$ of global cargo, and the amount of delivery and adherence to a set delivery time are key factors of the industry. Although the reduction in ship fuel consumption reduces GHGs, the economic logic of the industry is violated. Therefore, instead of reducing fuel consumption, alternative fuels should be developed. In the next section, we analyze the characteristics of alternative fuels for vessels.

\subsection{Characteristics of Alternative Fuels}

HFO has been used as a fuel for existing ships. The necessity for eco-friendly alternative fuels in vessels has recently increased due to efforts from the international community. In this study, the advantages and disadvantages of eco-friendly alternative fuels such as LNG, which is widely used in the shipping industry, bio-fuel, ammonia, and battery, were analyzed. The results are summarized in Table 2. Fuel for vessels must be eco-friendly; additionally, fuel supply, space utilization, and shipbuilding cost should be considered. Among the alternative fuels analyzed in this study, LNG garners attention as an eco-friendly fuel because it can be supplied stably, has infrastructures by continuous investments, and does not emit sulfides. However, LNG must be used strategically because its GHG reduction level is only $20 \%$. Hydrogen and ammonia are carbon-free fuels that can satisfy the IMO's GHG reduction strategy. Hydrogen technology development is in the early stage. It is necessary to pre-emptively develop applied technologies, such as liquid hydrogen storage below absolute temperature and high-pressure gas utilization. Furthermore, ammonia offers advantages of low production cost, zero carbon dioxide emission, and relatively low barrier to entry of liquefaction technology; however, its popularity as ship fuel depends on the corrosiveness resolution and toxicity problems.

Regarding the power source of vessels, conversion to an electric system is garnering attention in consideration of the scalability of operation efficiency and the use of eco-friendly alternative fuels. In particular, the battery is considered as the eco-friendliest fuel, with zero emissions in principle. However, due to the limitations of the current battery technology, the development of punctual short-distance vessels must be prioritized based on the constraint of vessel displacement and the resulting weight restriction. Technologies that accommodate large sizes should be developed after proving the effects.

\section{Technology Development Trends}

Many countries worldwide are developing various technologies and supporting policies to achieve GHG reduction goals via conversion to eco-friendly vessels. The policies and technology developments of various countries are summarized in Table 3.

The European Union is promoting "sea transportation strategies" to prepare for an eco-friendly competition from the shipping industry, including a reduction in GHG emissions, use of eco-friendly port facilities, and flagship projects for hydrogen ship development. Germany is developing new technologies under the "Maritime Agenda 2025 " policy to develop alternative fuels for vessels. The United States is promoting a strong air pollutant regulation policy in ports separately from the IMO. South Korea enforced the Act on Promotion of the Development and Distribution of Environment-friendly Ships in January 2020 and is supporting the policy to propagate eco-friendly vessels. As a result of policy support and technology development in these countries, technology development for carbon-free ships is

Table 2 Characteristics of alternate fuels

\begin{tabular}{|c|c|c|c|c|}
\hline \multirow{2}{*}{ Fuels } & \multicolumn{3}{|c|}{ Relative characteristic of technology } & \multirow{2}{*}{ Advantage and disadvantage } \\
\hline & TRL & Fuel supply & GHG reduction & \\
\hline Petroleum & 10 & 10 & 0 & $\begin{array}{l}\text { (A) Reliable fuel supply and usage of existing infrastructure } \\
\text { (D) Dissatisfaction of various regulations }\end{array}$ \\
\hline LNG & 9 & 4 & 20 & $\begin{array}{l}\text { (A) Reliable fuel supply and usage of existing infrastructure } \\
\text { (D) Unsatisfaction of GHG regulation and high investment costs }\end{array}$ \\
\hline LPG & 10 & 8 & 20 & $\begin{array}{l}\text { (A) Reliable fuel supply and usage of existing infrastructure } \\
\text { (D) High possibility of fire due to relative high specific gravity }\end{array}$ \\
\hline Electric powered & 5 & 2 & 65 & $\begin{array}{l}\text { (A) Zero emission of greenhouse gases } \\
\text { (D) Limited range due to battery size and capacity }\end{array}$ \\
\hline Hydrogen & 2 & 1 & 70 & $\begin{array}{l}\text { (A) High energy density, carbon-free fuel } \\
\text { (D) Initial stage of technology development }\end{array}$ \\
\hline Ammonia & 10 & 6 & 50 & $\begin{array}{l}\text { (A) Zero emission of greenhouse gas, ease of liquidization } \\
\text { (D) Corrosive and nitrogen oxide discharge }\end{array}$ \\
\hline Methanol & - & - & 50 & $\begin{array}{l}\text { (A) Low cost of bunkering } \\
\text { (D) Unsatisfaction of GHG regulations }\end{array}$ \\
\hline Bio-fuel & 10 & 9 & 72 & $\begin{array}{l}\text { (A) High compatibility with existing fuel } \\
\text { (D) Sediment generation and limited production while fuel usage }\end{array}$ \\
\hline
\end{tabular}


Table 3 Trends in the development of eco-friendly ship related policies and technologies in several countries

\begin{tabular}{|c|c|c|}
\hline Section & Country & Content \\
\hline \multirow{5}{*}{$\mathrm{R} \& \mathrm{D}$} & Europe & Evaluation of existing technical methods for 11 future ships for reduction of greenhouse gases \\
\hline & Norway & Construction of eco-friendly fuel supply facility, demonstration of next generation ship in sea \\
\hline & South Korea & Eco-friendly technology development based on advanced shipbuilding technology \\
\hline & Japan & Demonstration of $8,000 \mathrm{t}$ liquefied hydrogen transport ship and the development of alternative fuel technology \\
\hline & Singapore & Development of standards for advanced LNG bunkering technology with maritime transport Industries \\
\hline \multirow{5}{*}{$\begin{array}{l}\text { Policy } \\
\text { support }\end{array}$} & Europe & Provide loans of up to $50 \%$ of the cost of overheating eco-friendly shipping investment \\
\hline & Norway & Financial support required for the construction and renovation of LNG-powered ships up to $80 \%$ of the overall costs \\
\hline & South Korea & Legislation on support of tax and promotion of eco-friendly ships \\
\hline & Japan & Support for the construction of shipping facilities and LNG bunkering vessels at Yokohama Port \\
\hline & Singapore & Tax reduction and subsidy support for eco-friendly ships \\
\hline
\end{tabular}

actively performed. A carbon-free ship refers to a ship that is fully powered by electricity using a battery, i.e., without requiring an internal combustion engine.

Regarding fully electric propulsion vessels, the introduction of punctual short-distance coastal passenger ships is being promoted worldwide. Norway has been operating a fully electrified car ferry (MF Ampere), which operates 34 times per day for a distance of 5.6 $\mathrm{km}$ in fjords since May 2015. This vessel measures $80 \mathrm{~m}$ (length) $\times 20$ $\mathrm{m}$ (width) and comprises two $450 \mathrm{~kW}$ propulsion systems. Furthermore, Norway has installed an electric charging facility, including an energy storage system (ESS) of approximately $400 \mathrm{kWh}$ in a berth pier for ship batteries (Korea Energy Agency, 2017). Based on the achievement of MF Ampere, Norway has been operating the vessel "Future of the Fjords" for tourism in fjords since April 2018. Future of the Fjords can accommodate 400 passengers, consumes 1.8 MWh of power from batteries on board, and has an operating speed of approximately $29 \mathrm{~km} / \mathrm{h}$. Photographs of the Future of the Fjords are shown in Fig. 1.

In addition to the abovementioned vessels operating in constanttemperature waters, Norway has been developing a container cargo ship (YARA Birkeland) with fully electric propulsion and autonomous navigation features since 2017. This ship is expected to have an operating speed of $12^{-} 15 \mathrm{kn}\left(6^{-}-8 \mathrm{~m} / \mathrm{s}\right)$ and support approximately 100 containers. An image of the YARA Birkeland under development is shown in Fig. 2.
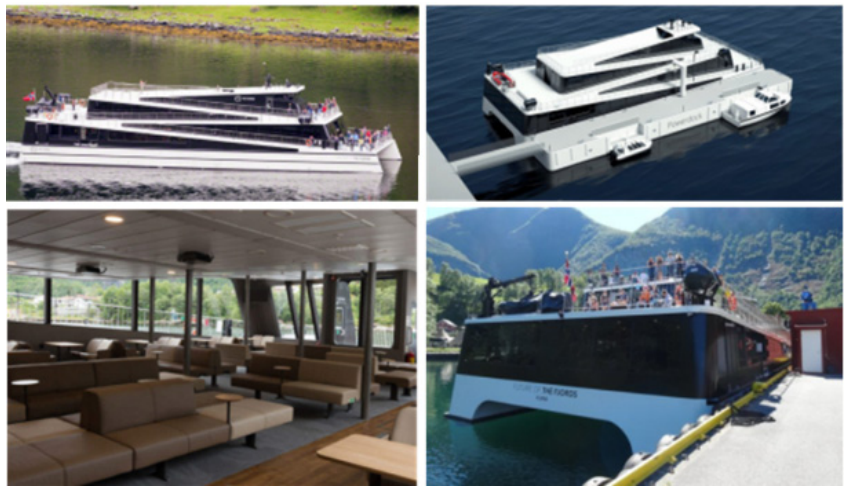

Fig. 1 Future of the Fjords in Norway, 2018
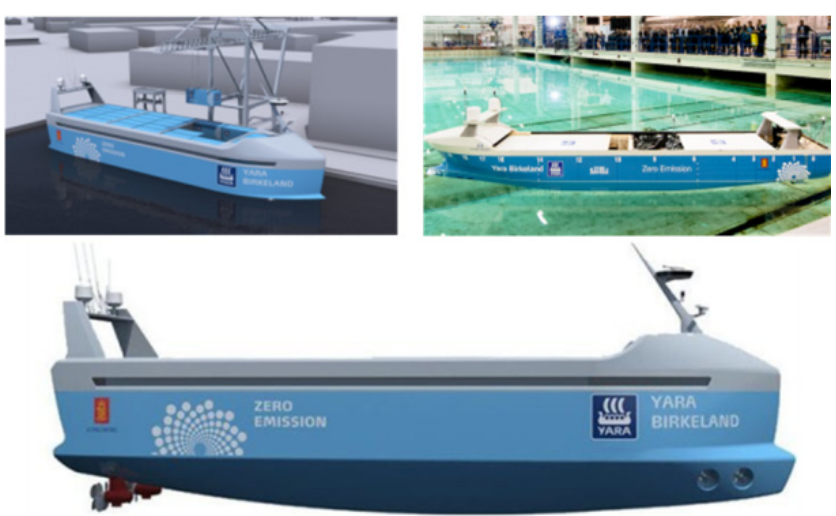

Fig. 2 Autonomous transport electric container cargo ehip (YARA) in Norway
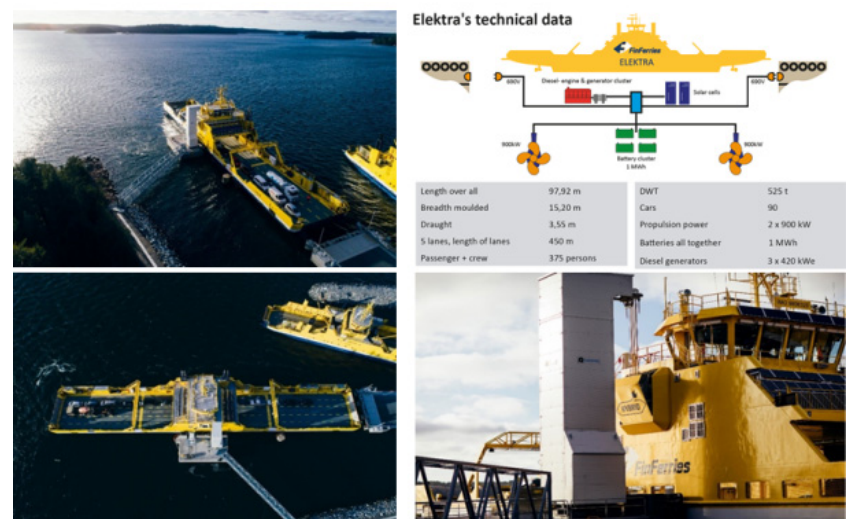

Fig. 3 Elektra in Finland (2017)

Finland has been operating a fully electrified car ferry that operates 25 times per day for a round trip distance of approximately $3 \mathrm{~km}$ in the Turku Islands since January 2017. The vessel is named Elektra (Fig. 3); it measures $97.92 \mathrm{~m}$ (length) $\times 15.2 \mathrm{~m}$ (width) and can transport approximately 370 passengers and 90 vehicles. Elektra comprises two propulsion systems with $900 \mathrm{~kW}$ capacity and $1 \mathrm{MWh}$ power consumption from batteries. A $690 \mathrm{~V}$ charging facility was installed at a pier to charge this vessel.

Iceland and Canada are planning to introduce electric propulsion vessels that have been proven effective in Europe and Norway to their 


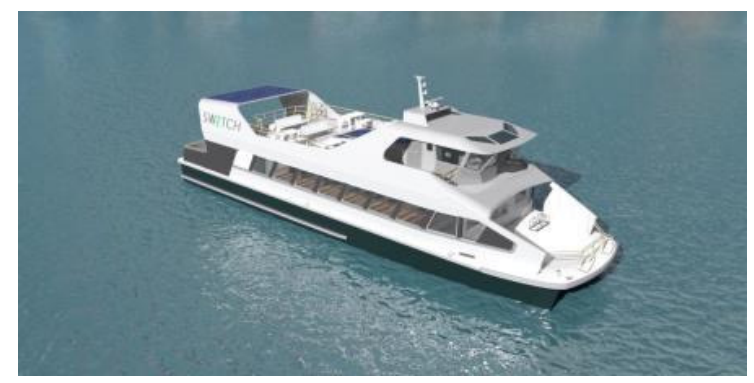

Fig. 4 Pure electric propulsion ship in America

domestic coasts. These vessels are punctual coastal ferries for transporting vehicles and passengers. Furthermore, the U.S. has recognized the necessity for electric propulsion vessels and is currently developing an E-ferry that can transport over 150 passengers between Williamsburg and East Manhattan (Fig. 4).

As described above, Europe and North America are developing and supplying battery-powered fully electric propulsion vessels in calm waters (e.g., fjords, rivers, and lakes). This provides evidence that punctual vessels operating a short distance can solve problems associated with the battery system's weight and volume.

China, which has well-developed inland canals around the Yangtze and Yellow River, is developing technologies through demonstration for coastal vessels that do not need to satisfy international standards. One example is an electric propulsion container ship built in November 2017 (Fig. 5) that measures approximately $70 \mathrm{~m}$ (length) $\times$ $14 \mathrm{~m}$ (wide) with a battery consumption of approximately $2.4 \mathrm{MWh}$. This inland ship is operated on the Pearl River in Guangzhou and can operate for up to $80 \mathrm{~km}$ by charging for two hours at a time.

South Korea, a global shipbuilding industry leader, is primarily developing hybrid ships used in combination with diesel engines and generators instead of using fully electric propulsion vessels. Examples include the icebreaker Araon and the LNG fuel vessel Econuri. The Araon was introduced in 2009 for polar research; it is driven by an electric propulsion system using a diesel generator. An electric propulsion system, which can actively respond to rapid output variations and be accurately controlled, is typically applied to offshore support vessels. An electric propulsion system for supplying materials, rescuing stranded fishing boats, and collecting polar samples has been applied to the Araon. The Econuri is a port guide ship that the Incheon Port Authority is operating; it generates electricity using an LNG/diesel dual-fuel generator. As the first LNG-powered vessel in Asia, the Econuri reduces the operation cost by approximately 100 million KRW per year compared with diesel vessels. The photographs of the Araon and the Econuri are shown in Fig. 6.

South Korea has more than 80,000 registered vessels and various types of small vessels (e.g., fishing boats and leisure yachts). To satisfy the eco-friendly policies of the global community, eco-friendly vessels using electric energy are being actively investigated, e.g., the application of a hybrid power generation system with wind and solar cells applied to a leisure boat (Oh et al., 2016) and a localization study pertaining to electric propulsion outboards for imported small ships (Moon et al., 2018).

Countries worldwide are competing with each other in developing technologies for eco-friendly vessels. Europe is leading the development of fully electric propulsion vessels for calm waters, whereas Asia uses technologies that apply a hybrid system with an existing ship engine to merchant ships. However, for the active management of pollutants generated on coasts in the future, technologies for fully electric propulsion vessels using batteries during ship operation should be developed for various ship types.
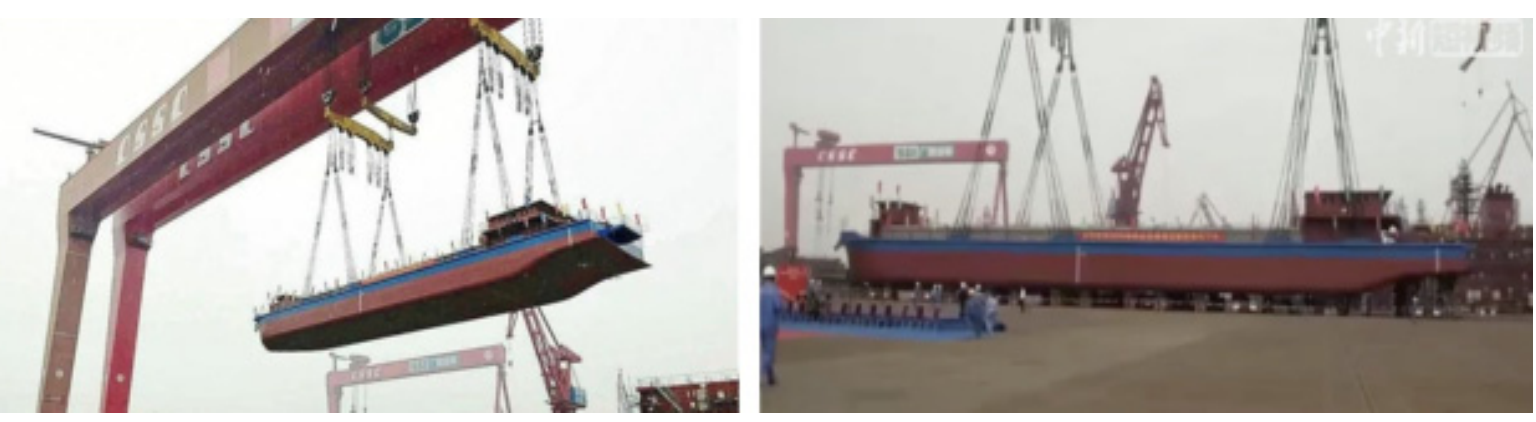

Fig. 5 Pure electric propulsion container ship in China
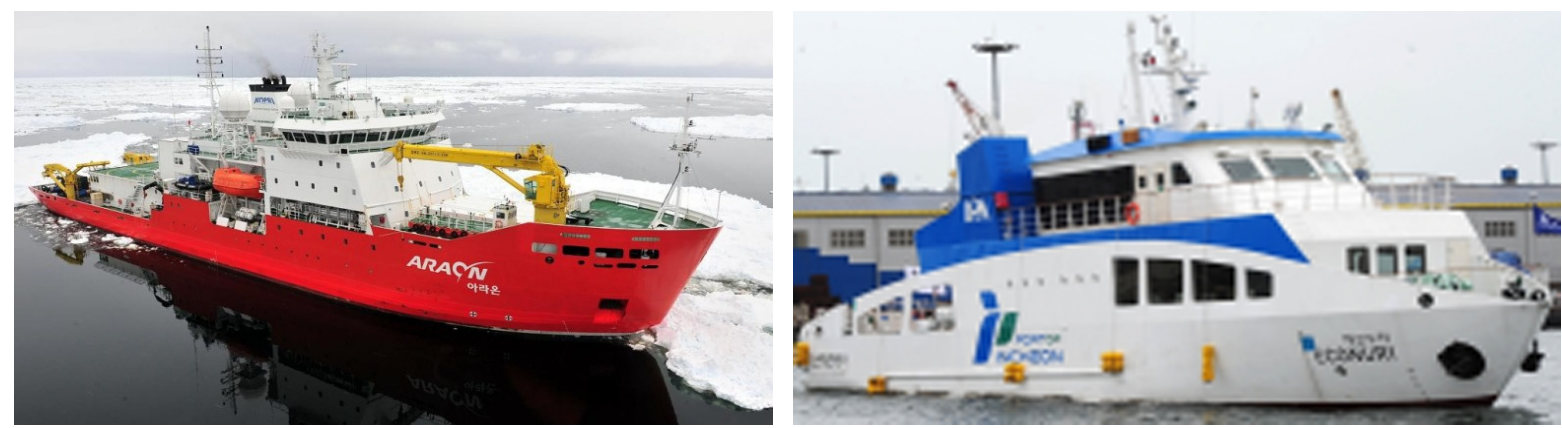

Fig. 6 Araon (left) and Econuri (right) 
Table 4 Registered ship statistics of Korea

\begin{tabular}{lccccccc}
\hline \multicolumn{1}{c}{ Tonne } & Total (ship) & Passenger ship & Cargo ship & Oil tanker & Tug-boat & Barge & Etc. \\
\hline Total & 8,953 & 337 & 653 & 768 & 1,212 & 1,864 & 4,119 \\
$<5 \mathrm{t}$ & 1,733 & 8 & 2 & 1 & 3 & - & 1,719 \\
$<5-20 \mathrm{t}$ & 1,337 & 14 & 9 & 26 & 91 & - & 1,197 \\
$<20-30 \mathrm{t}$ & 738 & 19 & 47 & 48 & 163 & 39 & 422 \\
$<30-50 \mathrm{t}$ & 515 & 10 & 27 & 49 & 161 & 29 & 239 \\
$<50-100 \mathrm{t}$ & 793 & 42 & 35 & 92 & 224 & 129 & 271 \\
$<100-200 \mathrm{t}$ & 948 & 85 & 21 & 135 & 308 & 262 & 137 \\
$<200-300 \mathrm{t}$ & 571 & 43 & 5 & 28 & 204 & 243 & 48 \\
$<300-500 \mathrm{t}$ & 600 & 62 & 14 & 50 & 55 & 374 & 45 \\
$<500-1,000 \mathrm{t}$ & 527 & 34 & 19 & 60 & 2 & 394 & 18 \\
$<1,000-2,000 \mathrm{t}$ & 357 & 4 & 96 & 51 & 1 & 197 & 8 \\
$<2,000-5,000 \mathrm{t}$ & 396 & 7 & 130 & 107 & - & 146 & 6 \\
$<5,000-10,000 \mathrm{t}$ & 238 & 4 & 106 & 90 & - & 29 & 9 \\
$<10,000-20,000 \mathrm{t}$ & 70 & 5 & 46 & 6 & - & - & 13
\end{tabular}

\section{Conversion of Domestic Ships to Electric Propulsion Vessels}

\subsection{Current Status of Ships in South Korea}

Approximately 8,900 registered ships exist in South Korea, and they are classified by use into 337 passenger ships (3.8\%), 653 cargo ships (7.3\%), 768 oil tankers (8.6\%), and 1,212 tug boats (13.6\%). The classifications of the registered ships in South Korea by use and tonne are summarized in Table 4 . When barges without power are excluded, the sizes of cargo ships and oil tankers are primarily distributed in over 2,000 t, whereas passenger ships and tug boats are primarily distributed in less than 1,000 $\mathrm{t}$ (Ministry of Oceans and Fisheries, 2019).

Based on the previous section's analysis results, battery-powered pure electric propulsion vessels require batteries of greater volume and weight as the required power and energy increase. Therefore, it is inefficient to use batteries to operate the main propulsion engines of vessels sailing the oceans or vessels operating on unspecified routes. However, fully electric propulsion vessels are the most useful eco-friendly solution for ships that do not emit pollutants. Hence, considering the decrease of the battery price and the increase of the energy density in volume and weight through the battery technology development, the possibility of commercialization and expansion of fully battery-powered ships are highly promising. Therefore, it is believed that car ferries interconnecting islands would yield significant eco-friendly effects if they are converted to fully electrified vessels as public transportation operating on designated routes in South Korea.

\subsection{Areas Expected to introduce electric propulsion vessels}

As stated in the previous section, the ship type for pure electric propulsion vessels should be a car ferry for passengers that periodically operate on a fixed route. South Korea has 162 coastal passenger ships operating in 100 sea routes. As a peninsula surrounded by seas on three sides, South Korea has many small islands, and

Table 5 Registered ship statistics of South Korea Current status of coastal passengers by region in Korea

\begin{tabular}{ccccccccccc}
\hline Region & Busan & Incheon & Yeosu & Masan & Donghae & Gunsan & Mokpo & Pohang & Daesan & Jeju \\
\hline $\begin{array}{c}\text { Car ferry } \\
\text { (open space) }\end{array}$ & - & 11 & 11 & 16 & - & 4 & 59 & - & 6 & - \\
$\quad \begin{array}{c}\text { Car ferry } \\
\text { High-speed }\end{array}$ & 1 & - & 2 & - & - & - & 3 & - & - & 2 \\
$\quad$ car ferry & & 2 & - & - & - & - & - & 1 & - & - \\
$\begin{array}{c}\text { High-speed vessel } \\
\text { Ultra-high speed } \\
\text { vessel }\end{array}$ & - & 4 & - & - & - & 1 & 3 & 2 & - & 2 \\
General vessel & - & 1 & 2 & - & 4 & - & 7 & 3 & - & - \\
$\quad$ Total & 1 & 18 & 20 & 24 & 4 & 5 & 72 & 6 & 9 & 4 \\
\hline
\end{tabular}


coastal passenger ships interconnecting the islands with the land are considered public transportation. Hence, it is believed that when pure electric propulsion vessels are introduced, the effect of technology diffusion will be evident. Considering the maximization of effects arising from fully electrified car ferries and the possibility of mounting battery systems, the introduction of car ferries as a coastal passenger ship is regarded as appropriate. The introduction of fully electrified car ferries in the Mokpo area, where more than $60 \%$ of domestic car ferries are operated, will clearly reveal their difference from existing ships and emphasize their eco-friendliness. The current status of coastal passenger ships by region in South Korea are shown in Table 5 (Korea Shipping Association, 2019).

\subsection{Suggestion for introduction of removable power supply system for vessels}

Fully electric propulsion vessels are one of the most useful eco-friendly vessels that do not emit pollutants during operation. However, due to the high price of batteries, the building cost of a battery-powered ship with the same specifications is approximately twice that of building an engine powered ship. Hence, the initial investment cost will increase significantly, and passenger fares will increase accordingly, owing to the significant burden on shipping companies. Moreover, when batteries are embedded in vessels, because of the difference between the battery replacement life (10 years) and ships' operating life (25 years), an unintended operation loss will most likely occur, causing economic losses to the shipping company.

Removable power supply systems (battery systems) must be developed and supplied to solve such durability and initial investment cost problems. Because removable power supply systems are not installed inside a ship permanently and are replaced every cruising, operation loss due to service life differences can be prevented. After the spread of removable power supply systems is completed, an industry that can effectively operate and maintain ship batteries will emerge. The battery cost can be shared, thereby reducing the initial investment cost. This is expected to provide an opportunity to increase the competitiveness of the Korean coastal shipping industry through the establishment of a new ship battery supply business, similar to

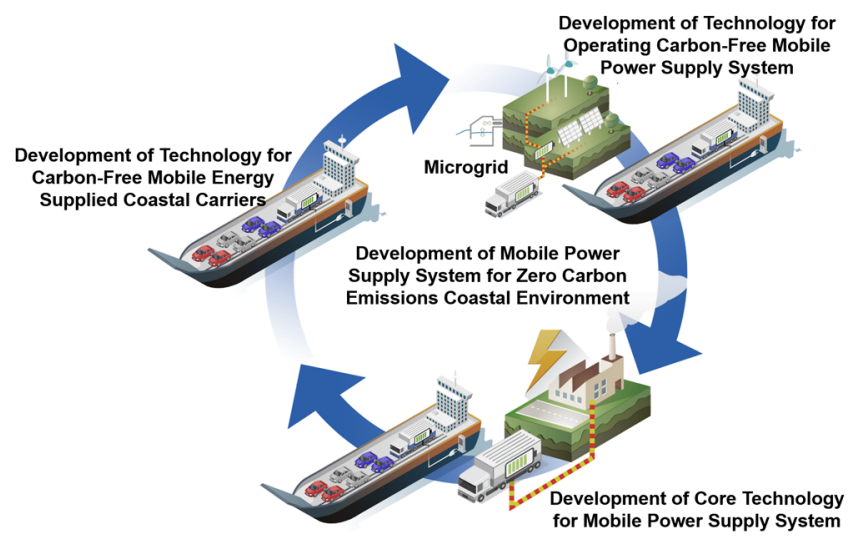

Fig. 7 Concept of fully electrified ferry for passengers and cars using affordable electricity on land. Furthermore, when this system is constructed, safe ports can be maintained because a high-voltage port infrastructure need not be installed. This can be a solution optimized for battery maintenance through the integrated management of ship batteries (Kim et al., 2019a; Kim et al., 2019b).

It is expected that the fuel cost of a car ferry, which can transport 300 passengers and 40 cars and operate round trips for two hours, will be reduced by approximately 200 million won per year when the removable power supply system instead of marine diesel (Kim. et al., 2019b). This concept is illustrated in Fig. 7.

\section{Fully Electrified Car Ferry Design Powered by Removable Power Supply System}

Vessels are built and operated based on rules stipulated by the classification society and maritime authorities. The removable power supply system proposed herein has not been applied to the rules of the classification society or maritime authority. This is because it is a new concept in this era of evolving ship fuels. It would be desirable to apply this concept to the rules after a more comprehensive review of safety is performed.

The car ferry was selected as the target vessel in this study because vehicles with a battery system can be easily loaded on the vessel as the removable power supply system. Moreover, the car ferry has not been applied to the international classification society's rules, which are severe to apply to the fully electrified vessel. A roll-on/roll-off type removable power supply system that can move by itself was applied to a fully electrified car ferry in order. This concept of a fully electrified car ferry with removable battery systems can give a technical advantage to overcome environmental weaknesses like big tidal differences and frequent typhoon occurrence to South Korea and other regions having similar coastal environments. Furthermore, this concept can achieve economic feasibility in the initial investment cost for fully electrified vessels. The principal dimensions of the vessel are outlined in Table 6 . The designed fully electrified car ferry can transport approximately 100 passengers and more than 20 passenger cars, has a power capacity exceeding 1.6 MWh, and can operate for approximately $2 \mathrm{hr}$ at the standard speed of $10 \mathrm{kn}(5.144 \mathrm{~m} / \mathrm{s})$.

Table 6 Principal dimensions of a fully electrified car ferry

\begin{tabular}{ccc}
\hline Category & Unit & Specification \\
\hline Length overall (LOA) & $\mathrm{m}$ & 58.6 \\
Length between & $\mathrm{m}$ & 49.0 \\
perpendiculars (LBP) & $\mathrm{m}$ & 13.0 \\
Breath & $\mathrm{m}$ & 2.5 \\
Depth & $\mathrm{m}$ & 1.65 \\
Draft & $\mathrm{km} / \mathrm{h}$ & 29 \\
Design speed & persons & 120 \\
Passengers & units & 20 \\
Cars &
\end{tabular}


Table 7 Design variables for removable power supply system

\begin{tabular}{cccc}
\hline System & Category & Unit & Specification \\
\hline & Number & set & 2 \\
& Size & $\mathrm{m}$ & $\begin{array}{c}6.1 \mathrm{~m} \text { container } \\
\text { specification }\end{array}$ \\
& Weight & $\mathrm{t}$ & $<12$ \\
$\begin{array}{c}\text { Power } \\
\text { supply } \\
\text { system }\end{array}$ & $\begin{array}{c}\text { Power capacity } \\
\text { Output reference } \\
\end{array}$ & $\mathrm{kWh}$ & 800 \\
& voltage & $\mathrm{Vdc}$ & 780 \\
& $\begin{array}{c}\text { Output voltage range } \\
\text { Reference }\end{array}$ & $\mathrm{Vdc}$ & $650-900$ \\
& /maximum voltage & $\mathrm{A}$ & $350 / 450$ \\
$\begin{array}{c}\text { Power } \\
\text { transportation } \\
\text { vehicle }\end{array}$ & Length & $\mathrm{m}$ & $<10$ \\
& Load weight & $\mathrm{t}$ & 12 \\
\hline
\end{tabular}

The roll-on/roll-off type removable power supply system must be equipped with a secondary battery, and a technology that ensures stability during vessel movement must be applied. The removable power supply system is designed as a self-moving system equipped with various safety systems; battery management system (BMS), cell anomaly detection system, thermal management system through air-conditioning, and battery thermal runaway limit system. Furthermore, the system will be designed based on the standardized ISO (the International Organization for Standardization) container size of $6 \mathrm{~m}$ to account for future scalability. The main design variables of the removable power supply system are outlined in Table 7 .

The fully electrified car ferry was designed to locate and safely fasten the roll-on/roll-off-type removable power supply system in a specified space in the vessel. Its layout was designed so that a removable power supply system can be placed separately from the passenger zone to enhance passenger safety and prevent secondary fire damage by installing additional fire extinguishing equipment. The general arrangement of the fully electrified car ferry with a removable power supply system is shown in Fig. 8.

The general arrangement shows that, unlike existing vessels, two removable power supply systems are located on the deck of the vessel, causing a change in weight by approximately $30 \mathrm{t}$; this results in a change in the vessel's center of gravity.

The car ferry's seakeeping performance was analyzed to analyze the effects of such a change in the center of gravity on the vessel's behaviors. It was assumed that the removable power supply system was installed on the deck or at the bottom of the vessel. The resultant change in the center of gravity was assumed to be approximately 10 $\mathrm{cm}$. The lines and wave spectrum used in the analysis of the seakeeping performance are shown in Figs. 9-10.

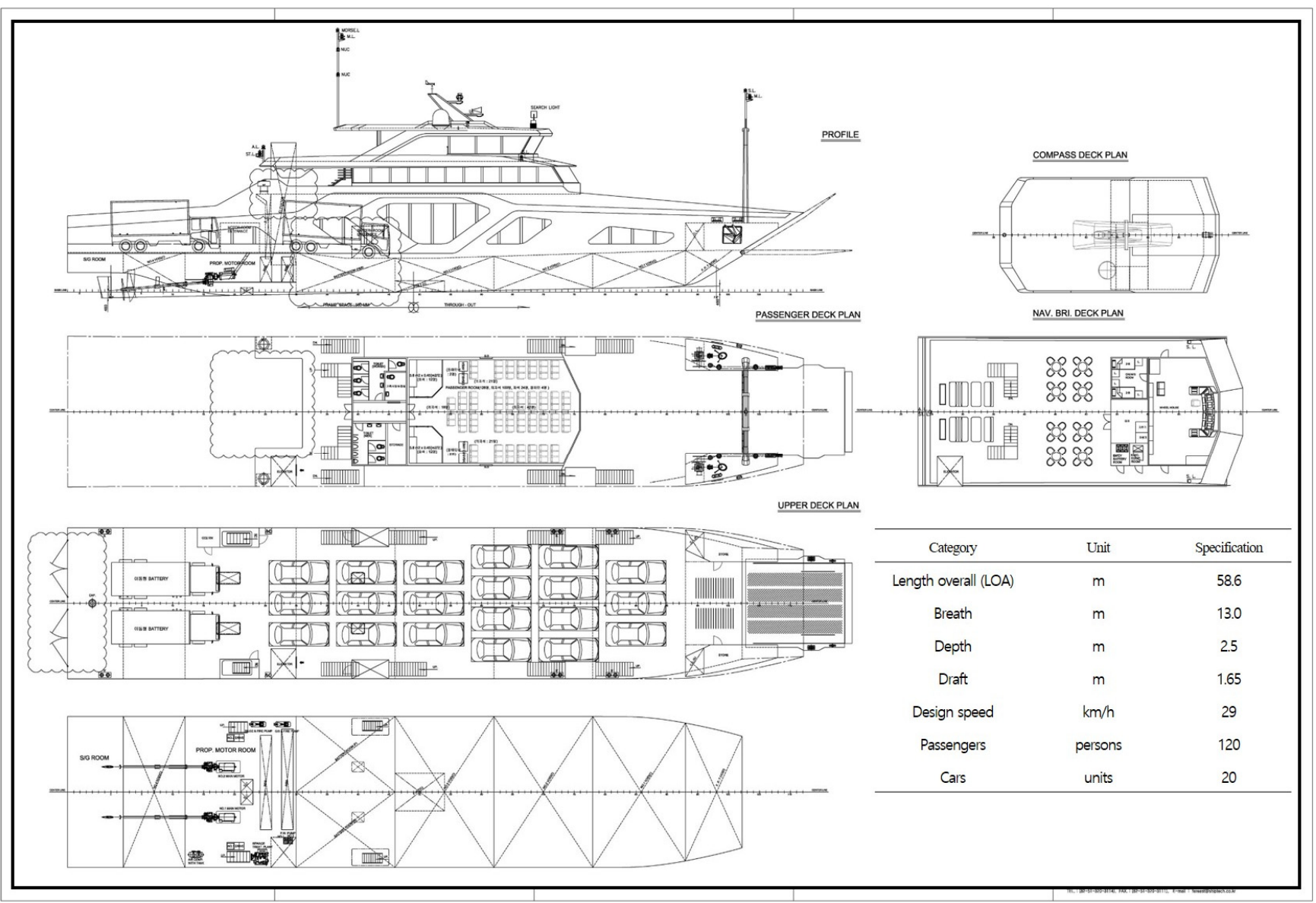

Fig. 8 General arrangement of a fully electrified car ferry 

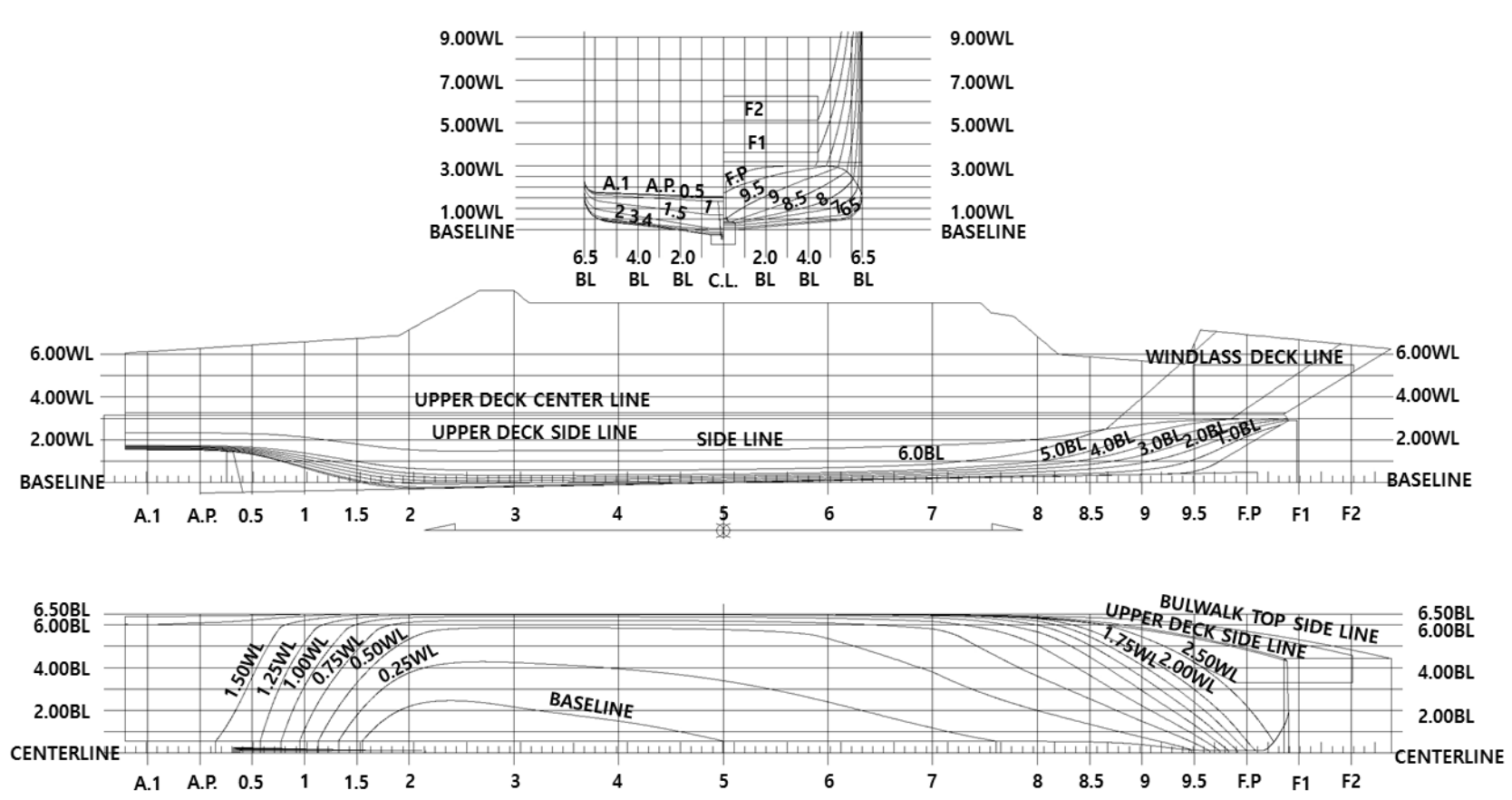

Fig. 9 Lines of a fully electrified car ferry

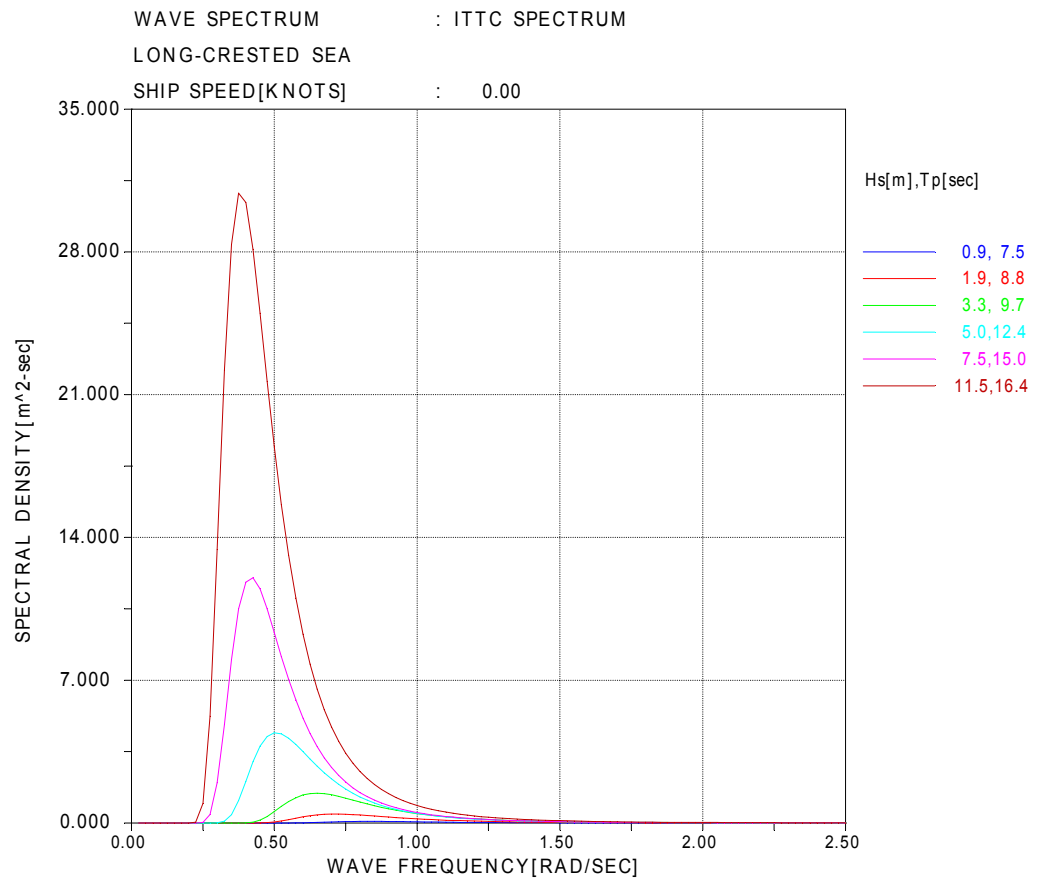

Fig. 10 Wave spectrum

An analysis of the change in behavior characteristics due to the change in the removable power supply system's position indicated that the behavioral changes due to the change in the center of gravity were insignificant. Furthermore, the behavior characteristics were determined by adding the ship speed to analyze the behavioral change characteristics at the ship's reference speed to be developed. The ship motion response amplitude operator (RAO) graphs based on the change in the center of gravity are shown in Fig. 11, and the changes in heave, pitch, and roll based on the ship speed are shown in Fig. 12.
The analysis result confirmed that the car ferry's behavior characteristics for guaranteeing the safety of passengers exhibited insignificant differences, based on the change in the location of the removable power supply system. Furthermore, ship safety is ensured if the removable power supply system is fastened appropriately.

The safety of the removable power supply system has not been proven because it is a new concept. Ships are characterized by relatively high safety standards and high entry barriers due to 


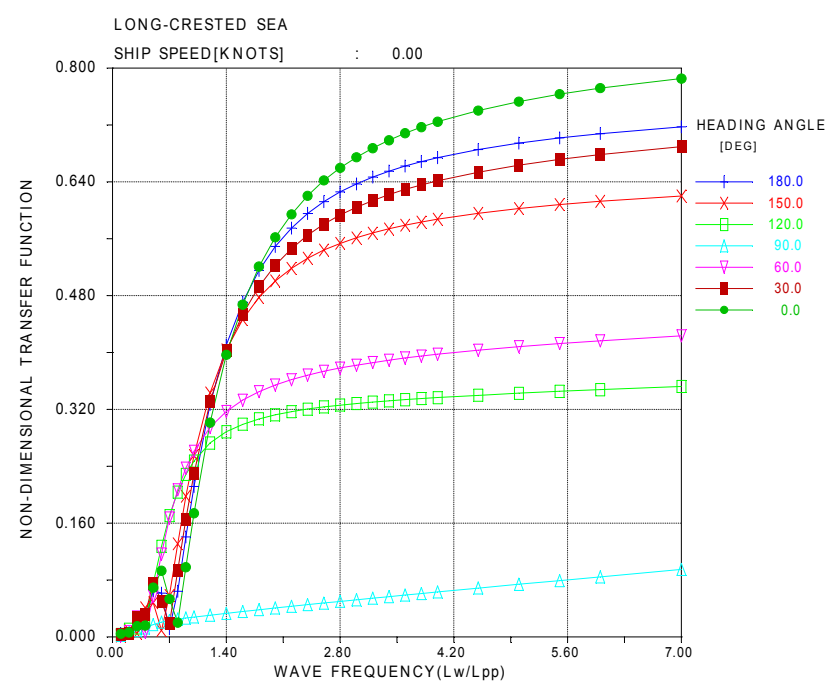

Surge RAO (CASE 1)

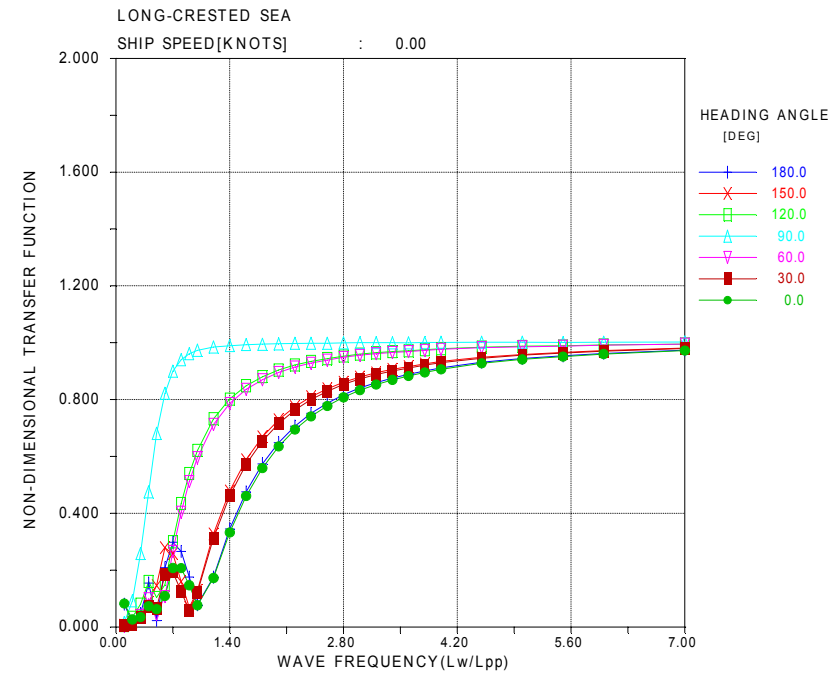

Heave RAO (CASE 1)

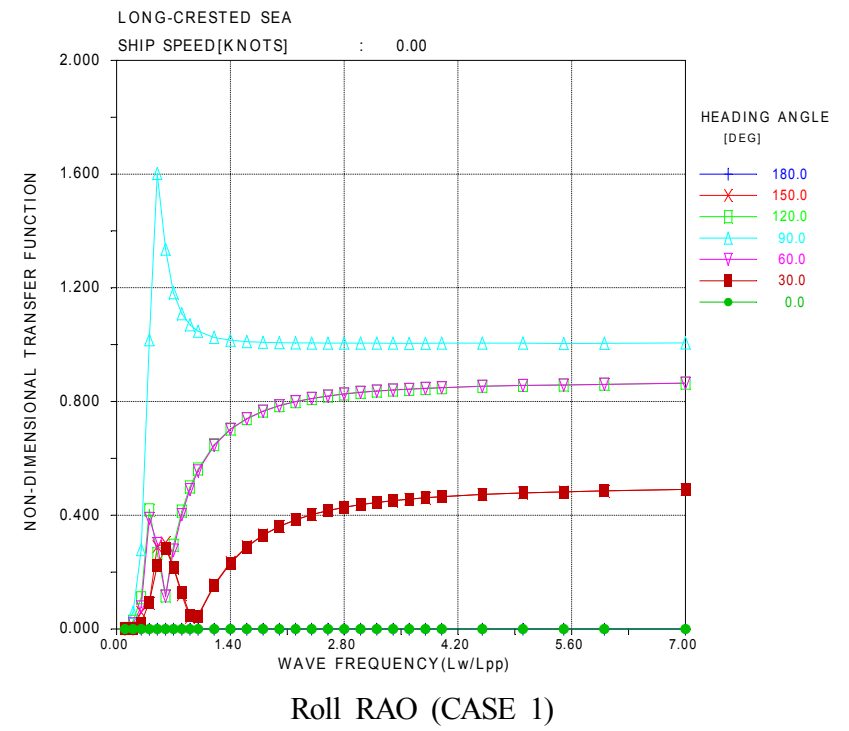

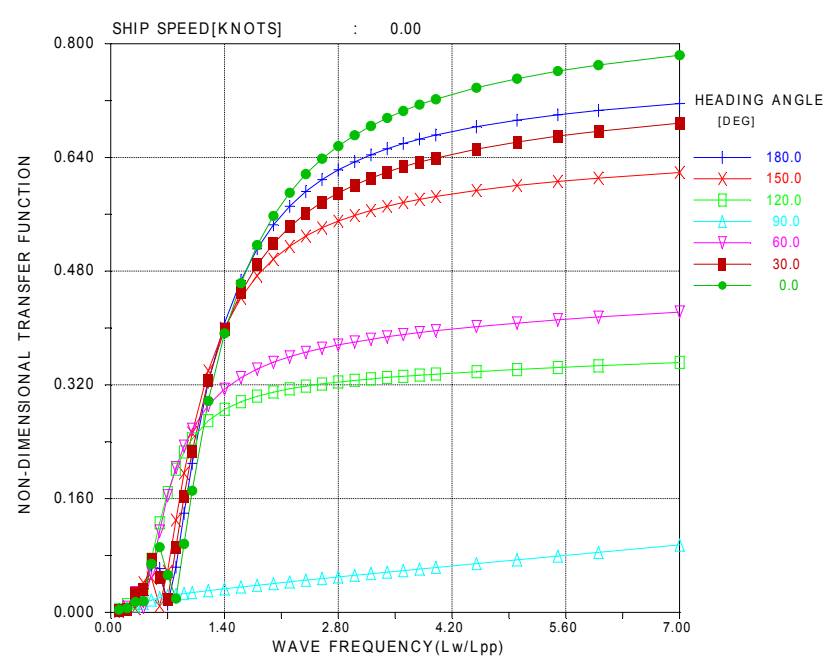

Surge RAO (CASE 2)

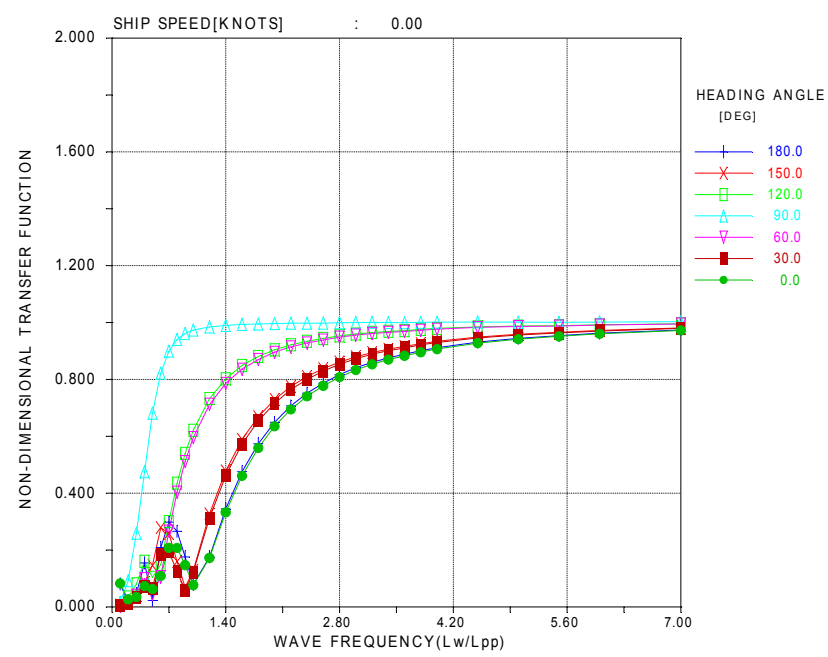

Heave RAO (CASE 2)

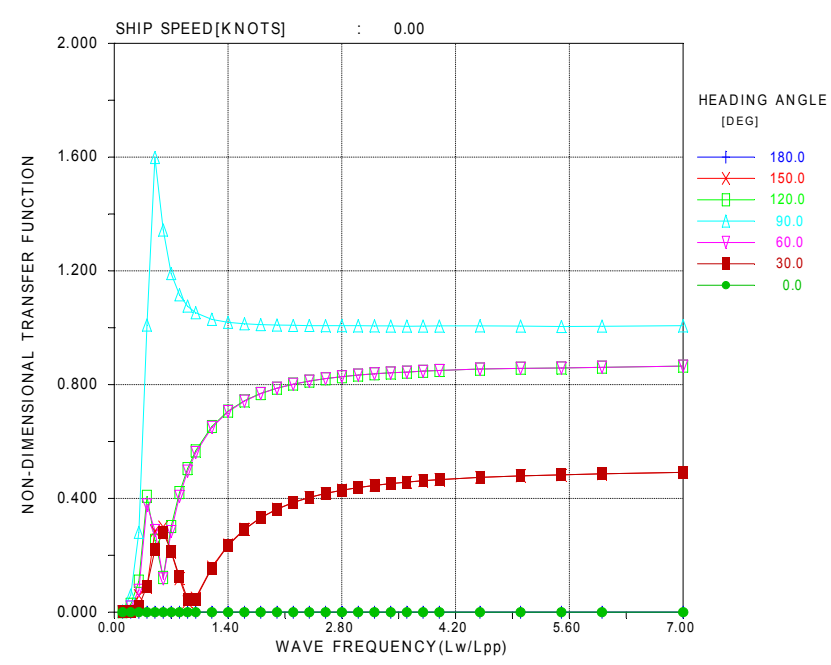

Roll RAO (CASE 2)

Fig. 11 Results of analysis of ship motion performance by conditions (change of center of gravity) 


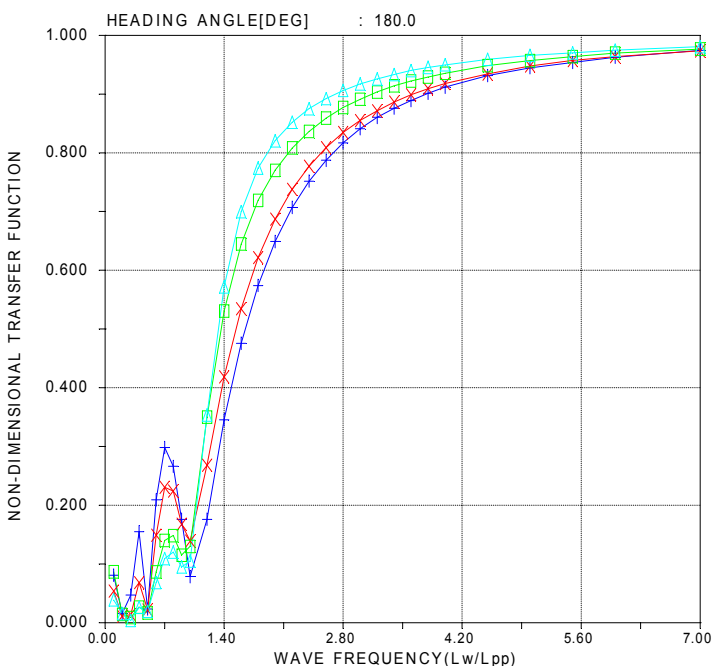

Heave RAO (Angle 180 ${ }^{\circ}$ )

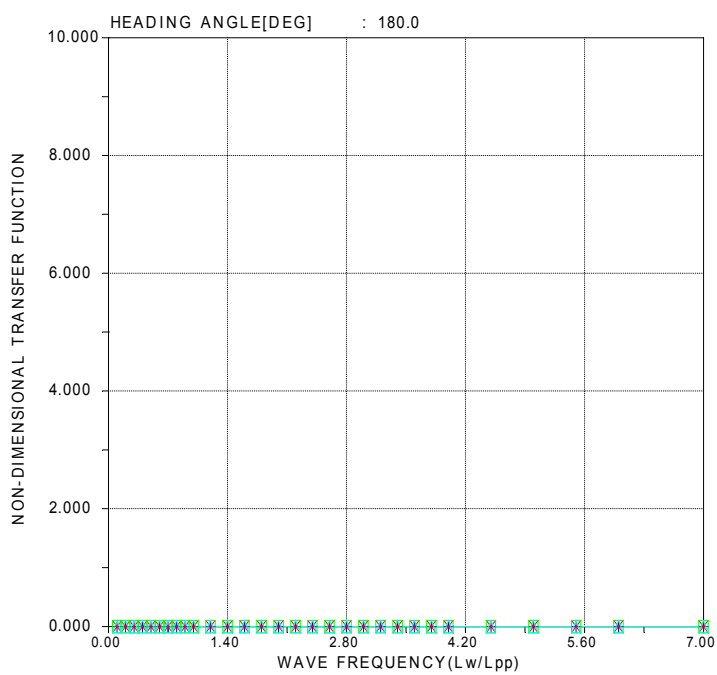

Roll RAO (Angle 180 ${ }^{\circ}$ )

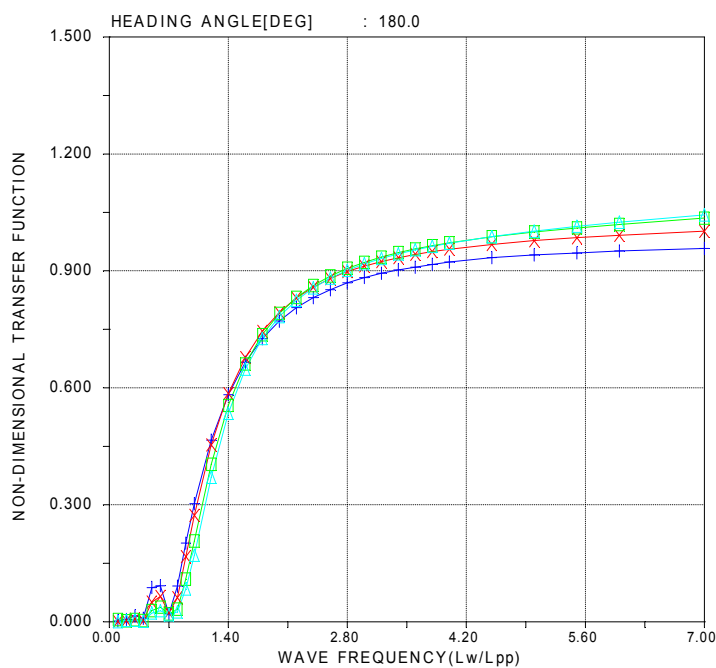

Pitch RAO (Angle $180^{\circ}$ )

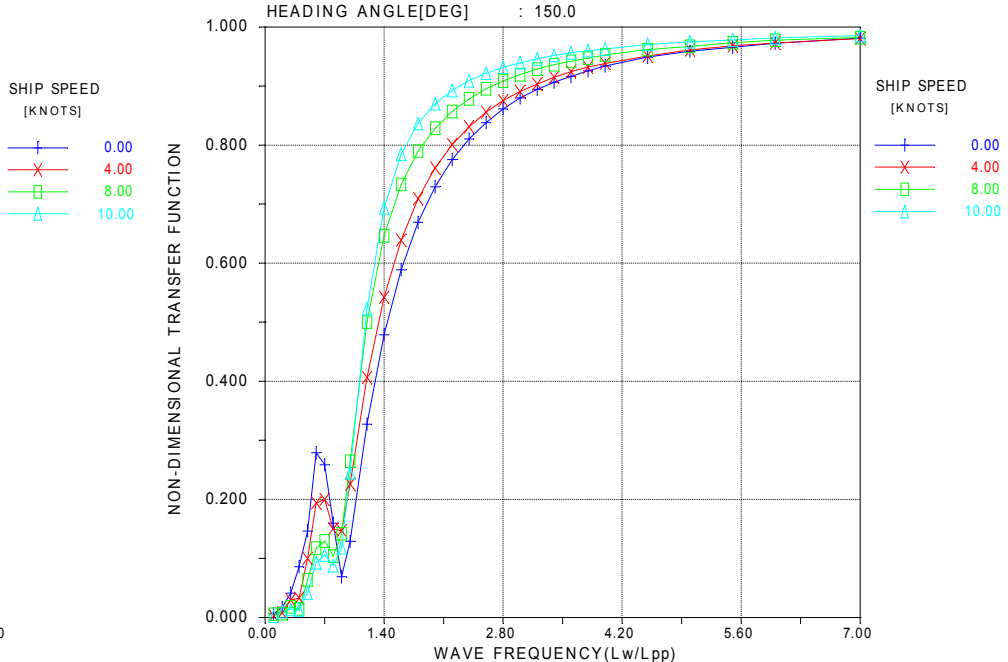

Heave RAO (Angle 150 ${ }^{\circ}$ )

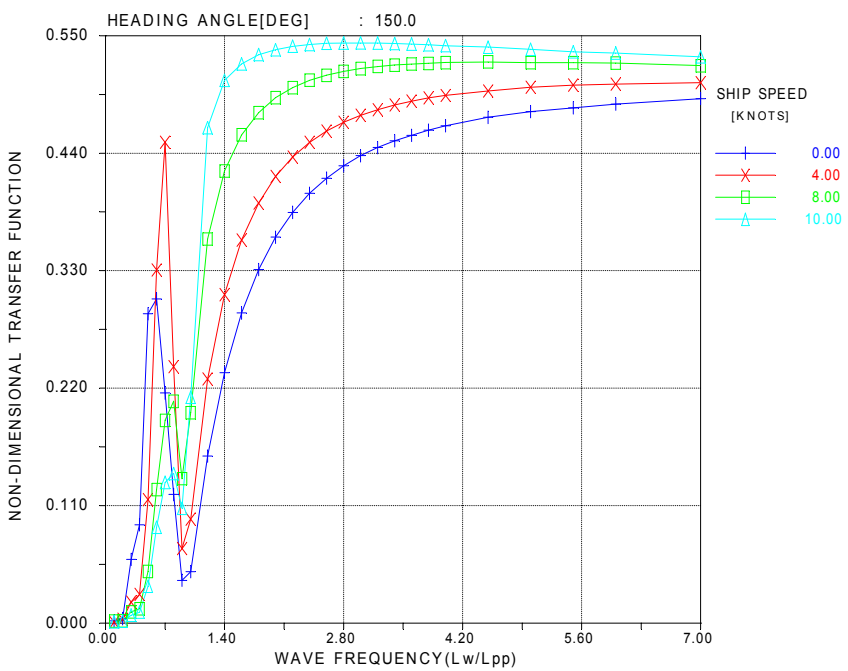

Roll RAO (Angle $150^{\circ}$ )

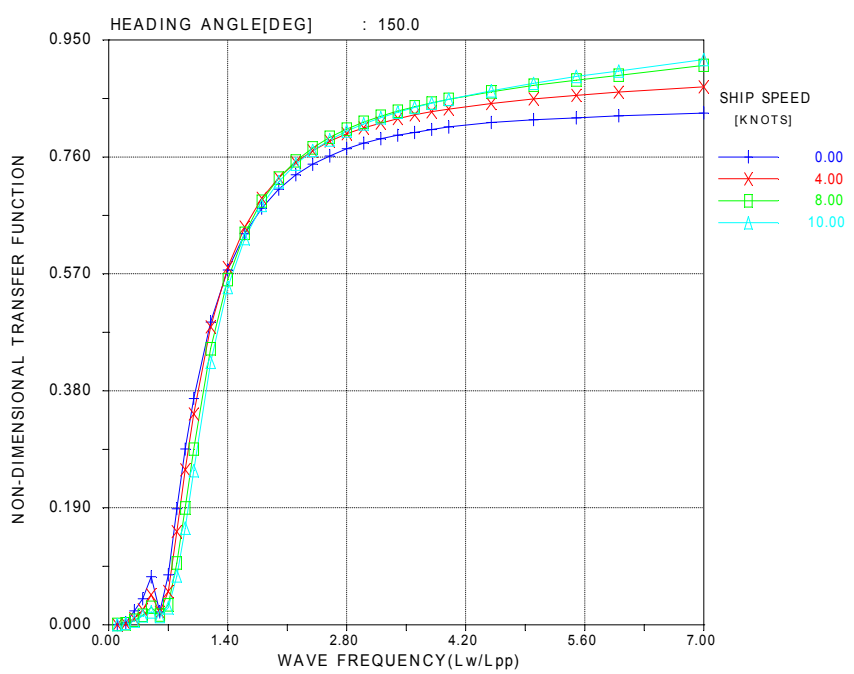

Pitch RAO (Angle $150^{\circ}$ )

Fig. 12 Results of analysis of ship motion performance per speed (change of angle) 
large-scale human damage and significant environmental effects due to accidents. The safety of the fully electrified car ferry developed in this study will be guaranteed through risk analysis. The best measures will be implemented, such as fire extinguishing and waterproofing systems for passenger safety.

\section{Future Plans and Prospects}

In the global trend of environmental protection and environmental preservation, fossil fuel has to be replaced by alternative fuels for shipping and shipbuilding industries according to GHG reduction strategy from IMO. In this study, the coastal shipping characteristics of South Korea were investigated, and the characteristics of emerging eco-friendly fuels were analyzed. Subsequently, a conceptual design of a fully electrified car ferry was presented for the conversion of coastal passenger ships to eco-friendly ships. The fully electrified car ferry to be developed in the future is the first of its kind. Hence, no relevant rules exist from the classification society, and hence appropriate preparations are required. To promote eco-friendliness in the shipping industry and encourage the introduction of new technologies, we plan to conduct further investigations such that safety will be secured and fully electrified car ferries can be developed and recognized by the classification society and the port authorities. An export model of this ship will be developed and is expected to be exported to neighboring countries with similar environments to activate the shipbuilding market for small and medium businesses in South Korea.

In the future, we plan to estimate the resistance of vessels through model tests based on concepts and basic designs as well as enable new-concept ships to operate safely in our country's territorial waters through risk analysis.

\section{Funding}

This study was conducted under the support of the "The development of a fully electrified car ferry and a removable power supply system (20200469-01, PMS4420)," which is a national R\&D project of the Ministry of Oceans and Fisheries. Additionally, we would like to express our sincere gratitude for the research fund granted.

\section{References}

Kim. J.H.,, Kim, J.H., \& Lee, J.Y. (2018). IMO's Initial Strategies for Reducing Ship Greenhouse Gases(in KOREA). International Journal of naval architecture and ocean engineering, 55(2), 2427. http://www.snak.or.kr/02 journal/journal01.htm Oh, K.G., Moon, B.Y., \& Lee, K.Y. (2016). Performance Evaluation and Technical Development of Eco-environmental Photovoltaic Leisure Ship with Sail-controlling Device With Respect to Solar-Hybrid Generating System. Journal of Ocean Engineering and Technology, 30(1), 57-67. https://doi.org/10.5574/KSOE 2016.30.1.057

Jeong, Y.-K., Lee, D.K., Jeong, U.-C., Ryu, C., Oh, D., \& Shin, J.G. (2013). Study on Operating Performance Estimation Process of Electric Propulsion Systems for 2.5 Displacement Ton Class Catamaran Journal of Ocean Engineering and Technology, 27(5), 1-9. https://doi.org/10.5574/KSOE2013.27.5.001

Moon, B.Y., Shin, K.H., \& Lee, K.Y. (2018). Performance Evaluating of 20 HP Outboard Motot in Consideration of Driving System Applied to Electric-Propulsion Boat. Journal of Ocean Engineering and Technology, 32(6), 518-526. https:// doi.org/10.26748/KSOE.2018.32.6.518

Kim, Y.-S., Shim, H.-W., \& Jung, S.-J. (2019a). A Concept Study On and All Electrified Passenger Car Ferry and Its Removable Electric Power Supply System. Proceedings of Fall Conference of Ocean Engineering and Technology, Gimhae, Korea, 83-85.

Kim, Y.-S., Shim, H.-W., Kang, H.-J., \& Jung, S.-J. (2019b). A Concept Study of an All Electrified Passenger Car Ferry Based on Movable Power Supply System. Proceedings of the Korean Society for Power System Engineering, Jeju, Korea, 41-42.

Ministry of Oceans and Fisheries. (2019). Registered Ship Statistics. Retrieved December 2019 from http://www.mof.go.kr/statPortal/ cate/partStat.do

Korea Energy Agency. (2017). Norway to Operate the Torld's First 100\% Electric Ship. Retrieved July 2017 from https://blog. naver.com/kea_sese/221061203587

Korea Shipping Association. (2019). Statistical Year book of Coastal Shipping(2019). Seoul, Korea: Korea Shipping Association.

Lee, I.-A. (2018). Lack of Response to Eco-friendly Facilities for Foreign Ships of Nationality. Retrieved June 2018 from http://m.monthlymaritimekorea.com/news/articleView.html?id xno22445

\section{Author ORCIDs}

$\begin{array}{ll}\text { Author name } & \text { ORCID } \\ \text { Hong, Jang Pyo } & 0000-0002-5054-2110 \\ \text { Kim, Young-Shik } & 0000-0001-5673-6314 \\ \text { Shim, Hyung-Won } & 0000-0002-7314-2881 \\ \text { Kang, Hee-jin } & 0000-0002-8241-3751 \\ \text { Kim, Yun-Ho } & 0000-0003-1465-5844 \\ \text { Kim, Gyu Bum } & 0000-0001-9960-4960 \\ \text { Cho, Seongpil } & 0000-0002-6613-4592\end{array}$

